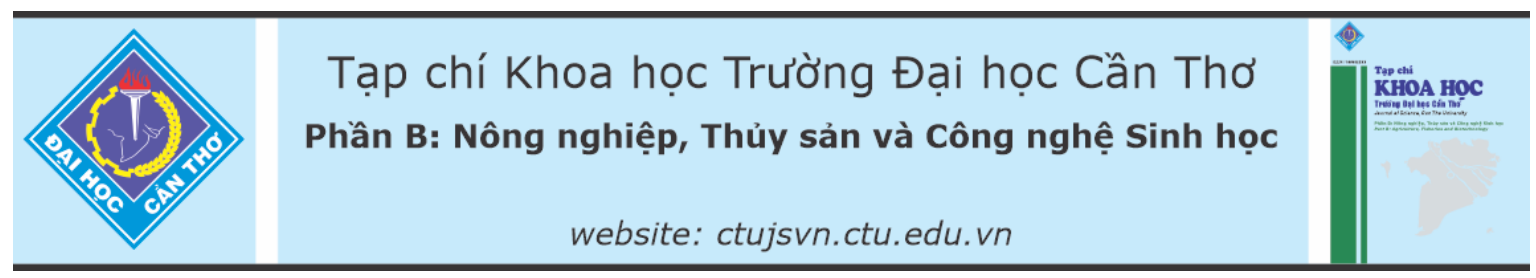

DOI:10.22144/ctu.jvn.2021.184

\title{
XÁC ĐỊNH THÀNH PHẦN VÀ TỶ LÊ PHỐI TRỘN TRONG SẢN XUẤT TRÀ HÒA TAN CATECHIN
}

Nguyễn Văn Toàn, Phạm Hải Sơn, Nguyễn Thị Liễu, Lê Thị Huyền, Võ Nguyễn Thanh Thảo, Nguyễn Xuân Hiếu và Nguyễn Thị Dung*

Trung tâm Công nghệ Sinh học Thành phố Hồ Chi Minh

*Người chịu trách nhiệm về bài viết: Nguyễn Thị Dung (email: thuydung9810@gmail.com)

\section{Thông tin chung:}

Ngày nhận bài: 14/06/2021

Ngày nhận bài sủa: 24/07/2021

Ngày duyệt đăng: 25/12/2021

\section{Title:}

Assessment of some mixing conditions product of instant catechin tea

\section{Tù khóa:}

Camellia sinensis, catechin, polyphenol, sấy phun, trà hòa tan

\section{Keywords:}

Camellia sinensis, catechin, instant catechin tea, polyphenol, spray-dried

\begin{abstract}
Catechin is an important extraction of bioactive compounds from green tea leaves (Camellia sinensis). Recent studies revealed catechin abilities in preventing and treating cancers, cardiovascular diseases, high blood pressure, intestinal diseases, oral diseases, slowing down the aging process and increasing the life expectancy. The study to investigate and evaluate some conditions to create instant tea products from catechin. The results showed that the extraction yield of catechin and sweet grass at $80^{\circ} \mathrm{C}$ for 1 hour using water solvent was $30.91 \%$ and $31.76 \%$, respectively. The total polyphenol content in the catechin extract was $327.47 \mathrm{mg} \mathrm{GAE} / \mathrm{g}$ extract. The total catechin content of the catechin extract was $558.77 \mathrm{mg} / \mathrm{g}$ GAE. The formula of the instant catechin tea product has the highest organoleptic rating score with the ratio of catechin: sweet grass: maltodextrin is 2:1:27 by weight. The dry matter concentration at $15 \%$ used in the spray drying process with the highest recovery efficiency was $83.20 \%$, and the product quality is very stable.
\end{abstract}

\section{TÓM TẮT}

Catechin là một hợp chất quan trọng được chiết xuất tù lá trà xanh (Camellia sinensis), có khả năng phòng ngùa và điều trị một số bệnh ung thu, bệnh tim mach, bệnh cao huyết áp, bệnh đuoơng ruột, bệnh răng miệng và có tác dụng làm chậm quá trình lão hoá và gia tăng tuổi tho. Mục tiêu của nghiên cứu nhằm khảo sát, đánh giá một số điều kiện phối trộn tạo sản phẩm trà hòa tan tù catechin. Kết quả tách chiết cao catechin và cỏ ngọt ở điều kiện gia nhiệt $80^{\circ} \mathrm{C}$ trong 1 giờ sư dụng dung môi là nước thu được hiệu suất lần luợt là 30,91\% và 31,76\%. Hàm luợng polyphenol tổng trong mẫu cao chiết catechin đạt 327,47 mg GAE/g cao chiết. Hàm luợng catechin tổng của mẫu cao chiết catechin là 537,65 mg/g GAE. Công thức phối trộn của sản phẩm trà hòa tan cho điểm đánh giá cảm quan cao nhất với tỷ lẹ phối trộn giũa cao catechin: cao cỏ ngọt : maltodextrin là 2:1:27. Nồng độ chất khô sủ dụng trong quá trình sấy phun cho hiệu suất thu hồi cao nhất $(83,20 \%)$ và chất luợng sản phẩm không đổi là $15 \%$. Sản phẩm trà hòa tan catechin đạt tiêu chuẩn chất luợng, các chi tiêu phân tích sản phẩm đều nằm trong khoảng giới hạn cho phép dụa trên các TCVN hiện hành. 


\section{GIỚI THIÊU}

Trà xanh (Camellia sinensis L.) là loại thực vật có lợi cho sức khoẻ với nhiều công dụng. Trà được sử dụng như một loại đồ uống và phương thuốc trong $\mathrm{y}$ học phương đông từ hàng ngàn năm nay. Theo báo cáo thị trường nông, lâm, thủy sản của Cục Xuất nhập khẩu năm 2020 (Bộ Công Thương), Việt Nam đứng thứ 5 trên thế giới về xuất khẩu các loại trà, đứng thứ 7 về sản xuất trà toàn cầu, sản lượng trà xuất khẩu là 137.000 tấn.

Nhiều nghiên cứu cho thấy hợp chất catechin trong trà xanh có hoạt tính chống oxy hóa mạnh (chiếm tới 30\% hàm lượng khô) đã được sử dụng rộng rãi và phổ biến trong mỹ phẩm và thực phẩm chức năng (Cabrera et al., 2006). Catechin thuộc nhóm chất flavonoid bao gồm các hợp chất chính như $(+)$-catechin $(\mathrm{C})$; (-)-epicatechin (EC); (+)gallocatechin (GC); (-)-epicatechin gallate (ECG); (-)-epigallocatechin (EGC) và (-)-epigallocatechin gallate (EGCG). Catechin có khả năng ức chế sự tạo thành mạch mới, ức chế tăng trưởng tế bào và cảm ứng tế bào chết theo chương trình (apoptosis), do đó catechin có khả năng ngăn ngừa và điều trị một số bệnh ung thư, bệnh tim mạch, bệnh cao huyết áp, bệnh đường ruột, bệnh răng miệng và có tác dụng làm chậm quá trình lão hoá và gia tăng tuổi thọ (Blanco et al., 2005). Catechin có khả năng ức chế các enzyme có nguồn gốc từ vi khuẩn và tiêu diệt các loại vi khuẩn làm hư hỏng thực phẩm và loại bỏ các độc tố do chúng gây ra do đó catechin là tác nhân kháng khuẩn được ứng dụng nhiều trong thực phẩm và là thành phần trong nhiều loại thực phẩm chức năng (Mueller et al., 2010). Catechin cũng có tác dụng kháng viêm (bệnh viêm khớp, bệnh liên quan tim mạch, ung thư,...), nhờ làm tăng cường sự tạo thành IL (Interleukin)-10, một cytokine quan trọng trong quá trình kháng viêm (Ly et al., 2015).

Hiện nay, các vấn đề về ô nhiễm môi trường, dịch bệnh, áp lực từ công việc, tài chính đang không ngừng tác động tiêu cực đến chất lượng cuộc sống của con người, đặc biệt là sức khoẻ. Xã hội phát triển, nhu cầu chăm sóc sức khoẻ tăng cao, người tiêu dùng luôn tìm kiếm các sản phẩm chức năng bổ trợ có tác dụng phòng ngừa bệnh, thay thế thuốc kháng sinh, đặc biệt có nguồn gốc từ tự nhiên. Với nhu cầu của thị trường hiện tại, việc nghiên cứu và ứng dụng các hợp chất tự nhiên có dược tính cao và an toàn vào lĩnh vực thực phẩm chức năng, $\mathrm{y}$ dược đã thôi thúc các nhà nghiên cứu không ngừng tìm hiểu, cải tiến, phát triển và cho ra thị trường nhiều sản phẩm bổ trợ sức khoẻ dưới nhiều hình thức khác nhau, điển hình là trà hoà tan từ thảo dược. Từ các kết quả nghiên cứu về công dụng của hợp chất catechin và nhu cầu lớn của thị trường hiện nay, có thể thấy được việc sử dụng cao chiết catechin từ trà xanh để tạo ra một loại sản phẩm có giá trị cao cho sức khỏe của con người là thật sự cần thiết. Mặc khác, sử dụng cao chiết cỏ ngọt để thay thế cho đường tạo vị ngọt tự nhiên cho sản phẩm cũng giúp nâng cao đặc trưng và chất lượng cho sản phẩm bởi vì trong cao chiết cỏ ngọt cũng chứa nhiều hợp chất polyphenol tốt cho sức khỏe của con người. Vì vậy, việc nghiên cứu phối trộn cao chiết catechin từ trà xanh với cao chiết cỏ ngọt và chất mang maltodextrin là một hướng đi có giá trị ứng dụng cao trong ngành thực phẩm.

\section{VÂT LIỆU VÀ PHƯƠNG PHÁP NGHIÊN CÚU}

\subsection{Vật liệu}

Lá trà xanh thu hái tại Bảo Lộc - Lâm Đồng, giống trà được xác định là Camellia sinensis, cỏ ngọt (Stevia rebaudiana) khô (độ ẩm từ 12-15\%) được thu mua tại Công ty TNHH TM XNK Phúc Đại Thịnh, maltodextrin có DE từ 10 - 12 được mua tại cty TNHH XNK Sài Gòn Chem (dùng cho thực phẩm).

\subsection{Phương pháp nghiên cứu}

\subsubsection{Phuong pháp thu thập và xủ lý so bộ mẫu}

Lá trà xanh được thu hái, rửa sạch và tiến hành ức chế enzyme polyphenol oxidase (PPO) bằng cách sao (nhiệt độ $95-100^{\circ} \mathrm{C}$, thời gian từ $5-7$ phút) (Nguyễn Xuân Duy, 2013). Tiếp theo, trà được sấy ở nhiệt độ $105^{\circ} \mathrm{C}$ trong thời gian $30-40$ phút và sau đó được nghiền trà thành bột mịn tạo thành bột trà. Bột trà xanh được phân nhỏ lượng $100 \mathrm{~g}$ và bảo quản trong bao bì kín, sạch khô, tránh ánh sáng ở nhiệt độ $4^{\circ} \mathrm{C}$ để tiện sử dụng cho các lần thí nghiệm sau.

\subsubsection{Phuoong pháp xác định hàm luợng polyphenol tông (TPC)}

Hàm lượng polyphenol tổng được xác định theo phương pháp Folin-Ciocalteu (Vuong et al., 2013), có sửa đồi. Pha loãng 4 mẫu cao chiết bằng methanol đạt nồng độ $1 \mathrm{mg} / \mathrm{mL}$. Tiến hành hút $1 \mathrm{~mL}$ cao chiết vào $5 \mathrm{~mL}$ thuốc thử Folin-Ciocalteu $10 \%$. Để phản ứng trong 10 phút. Sau đó thêm $4 \mathrm{~mL}$ dung dịch $\mathrm{Na}_{2} \mathrm{CO}_{3} 7,5 \%$ và ủ trong bóng tối. Sau 1 giờ phản ứng ở nhiệt độ phòng, đo độ hấp thụ bằng máy đo quang phổ UV-vis ở bước sóng $765 \mathrm{~nm}$. Thí nghiệm được lặp lại 3 lần. Xây dựng đường chuẩn gallic acid, sau đó dựa vào đường chuẩn gallic acid để xác định hàm lượng TPC trong mẫu. 

thức:

Hàm lượng polyphenol tổng được tính theo công

$$
P=\frac{C . V}{m .1000}
$$

Trong đó: P: Hàm lượng polyphenol tổng số (mg $\mathrm{GAE} / \mathrm{g}$ cao chiết); $\mathrm{C}$ : nồng độ gallic acid quy ra từ phương trình chuẩn $(\mu \mathrm{g} / \mathrm{mL}) ; \mathrm{V}$ : thể tích dịch mẫu $(\mathrm{mL}) ; \mathrm{m}$ : khối lượng cao chiết dùng định lượng $(\mathrm{g})$.

\subsubsection{Phuoong pháp xác định hàm lượng catechin và các dẫn xuất}

Catechin thành phần được xác định bằng phương pháp HPLC-UV theo Wang et al. (2003), chất chuẩn sử dụng là $\mathrm{EGCG}, \mathrm{ECG}, \mathrm{EGC}, \mathrm{EC}$ và $\mathrm{GA}$. Hàm lượng caffeine được định lượng bằng phương pháp HPLC-UV. Đối với phương pháp này thì pha tĩnh sử dụng cột sắc ký pha đảo C18 $5 \mu \mathrm{m}(150$ x 4,6mm), pha động sử dụng hỗn hợp 2 dung môi orthophosphoric acid $0,1 \%$ và methanol được phối trộn theo tỷ lệ $0,5: 99,5$ (v:v). Tốc độ dòng là 1 $\mathrm{mL} /$ phút, mẫu được bơm vào với thể tích là $10 \mu \mathrm{L}$, nhiệt độ $30^{\circ} \mathrm{C}$. Bước sóng phát hiện từ $210-280 \mathrm{~nm}$ , giá trị UV nằm trong khoảng từ $200-400 \mathrm{~nm}$.

\subsubsection{Phuơng pháp phối trộn sản phẩm và đánh giá cảm quan}

Tiến hành bố trí các nghiệm thức cỏ ngọt với các khối lượng khác nhau 0,$025 ; 0,05 ; 0,075 ; 0,1$ và $0,125 \mathrm{~g}$ hoà tan với $100 \mathrm{~mL}$ nước nóng $\left(85-90^{\circ} \mathrm{C}\right)$. Sau đó sẽ tiến hành đánh giá cảm quan với 20 người để xác định nghiệm thức cho độ ngọt thích hợp.

Sau khi xác định được nghiệm thức cho độ ngọt thích hợp. Tiếp tục phối trộn các nghiệm thức bột cao chiết catechin ở các khối lượng 0,$1 ; 0,15 ; 0,2$; 0,25 và $0,3 \mathrm{~g}$ có bổ sung nghiệm thức cỏ ngọt đã xác định được ở thí nghiệm trên với $100 \mathrm{~mL}$ nước nóng $\left(85-90^{\circ} \mathrm{C}\right)$. Sau đó tiến hành đánh giá cảm quan với 20 người để xác định nghiệm thức cho màu sắc và mùi vị có chất lượng tốt nhất (Đặng Thị Yến và Đặng Quốc Tiến, 2018).

Phương pháp đánh giá cảm quan dịch trà được thực hiện dựa trên bộ tiêu chuẩn Việt Nam TCVN 3215-79 bằng cách cho điểm thị hiếu về mức độ ưa thích để đánh giá chất lượng của sản phẩm. Yêu cầu là dịch trà có màu sắc đẹp, trong, sáng, đặc trưng cho màu trà tốt; vị trà ngọt thanh, chát vừa, có độ trung hoà giữa 2 vị chát và ngọt, có hương thơm của trà đặc trưng của sản phẩm.

\subsubsection{Khảo sát ảnh hưởng của nồng độ chất khô đến hiệu suất thu hồi và chất lượng sản phẩm bằng công nghệ sấy phun}

Phương pháp khảo sát nồng độ chất khô được thực hiện theo nghiên cứu của Đặng Thị Yến và Đặng Quốc Tiến (2018) có điều chỉnh để phù hợp với điều kiện của nghiên cứu, nhằm tạo ra sản phẩm sau quá trình sấy phun cho hiệu suất thu hồi và chất lượng tốt nhất.

Khối lượng một gói sản phẩm trà hoà tan được đóng gói là $3 \mathrm{~g}$, dựa trên kết quả khảo sát tỷ lệ phối trộn cao chiết trà xanh và cỏ ngọt, từ đó sẽ đưa ra được hàm lượng maltodextrin để đạt đến khối lượng định mức cho một đơn vị sản phẩm.

Nồng độ chất khô sử dụng trong quá trình sấy phun được khảo sát ở các nghiệm thức $9,12,15$ và $18 \%$. Kết thúc quá trình sấy phun, tiến hành đánh giá hiệu suất thu hồi và chất lượng của sản phẩm để chọn ra nghiệm thức tốt nhất. Các thông số kỹ thuật cho quá trình sấy phun là nhiệt độ nhập liệu $160^{\circ} \mathrm{C}$, nhiệt độ đầu ra $85^{\circ} \mathrm{C}$, độ ẩm tương đối của môi trường $70 \%$, tốc độ nhập liệu $22,5 \mathrm{~mL} /$ phút , tốc độ phun là $30 \%$, áp suất khi nén làm quay đĩa phun là 4,25 par, năng suất sấy phun $0,5 \mathrm{~kg}$ sản phẩm/giờ.

\subsubsection{Phương pháp xử lý thống kê}

Số liệu thí nghiệm được xử lý bằng thống kê sinh học theo chương trình MiniTab 16.2.4.4.

\section{KẾT QUẢ VÀ THẢO LUẬN}

\subsection{Hàm lượng polyphenol tổng số và các dẫn xuất catechin trong mẫu cao chiết catechin}

Bột trà được hòa tan và chiết nóng với nước giúp các hợp chất thẩm thấu ra khỏi tế bào và hòa tan vào nước. Bột cao chiết có màu vàng nâu và mùi thơm đặc trưng của trà. Hiệu suất thu hồi cao chiết catechin là $30,91 \% \pm 0,15$. Kết quả này tương tự với nghiên cứu của Perva et al. (2006) trên cùng đối tượng cho hiệu suất thu hồi là $31,86 \% \pm 0,24$. Sự khác biệt nhỏ của kết quả đó có thể là do thời gian lấy mẫu, khu vực lấy mẫu, kỹ thuật tách chiết và các yếu tố khách quan khác.

Cao chiết cỏ ngọt được thu hồi cùng phương pháp tách chiết trên và nhận thấy hiệu suất thu hồi cao chiết cũng tương đối cao. Bột cao chiết cỏ ngọt có màu xanh đen và mùi thơm đặc trưng của cỏ ngọt. Hiệu suất thu hồi cao chiết nước cỏ ngọt là $31,76 \%$ $\pm 0,65$ cao hơn so với kết quả nghiên cứu của Tôn Nữ Liên Hương (2015) trên cùng đối tượng cho hiệu suất thu hồi là $22,67 \% \pm 0,65$. 

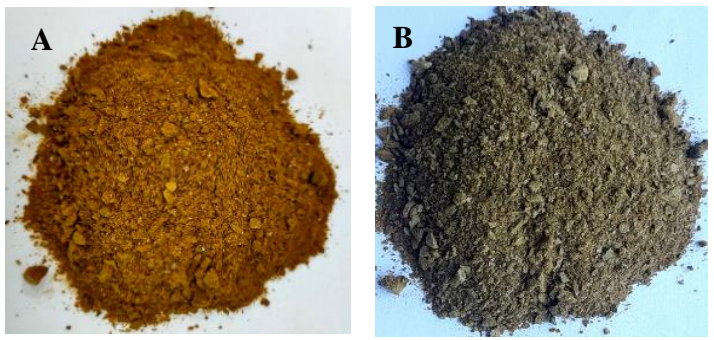

Hình 1. Bột cao chiết catechin và cỏ ngọt (A. cao chiết catechin, B. cao chiết cỏ ngọt)

Hàm lượng polyphenol tổng số được tính toán dựa theo đường chuẩn gallic acid được xây dựng có hệ số $\mathrm{R}^{2}=0,9963$. Từ kết quả xây dựng đường chuẩn nhận được hàm lượng polyphenol tồng trong mẫu cao chiết catechin là $327,47 \pm 0,54 \mathrm{mg} \mathrm{GAE} / \mathrm{g}$ cao chiết và tương đương với $100,21 \mathrm{mg} \mathrm{GAE} / \mathrm{g}$ chất khô. Theo kết quả nghiên cứu của Marja et al. (1999) trên tổng số của 92 loài thực vật ăn được và không ăn được cho thấy hàm lượng polyphenol dao động khá rộng trong khoảng từ $0,2-155,3 \mathrm{mg}$ GAE/g chất khô, đồng thời những loài thực vật có hàm lượng polyphenol tổng số lớn hơn $20 \mathrm{mg}$ GAE/g chất khô thì có hoạt tính chống oxy hóa mạnh. Qua đó, có thể thấy được hàm lượng polyphenol tổng số trong cao chiết nước catechin là khá cao so với các loại thực vật trong nghiên cứu trên, đồng thời đó sẽ là cơ sở để chứng minh trong mẫu cao chiết có sự hiện hữu của các hợp chất có hoạt tính kháng oxy hóa mạnh.

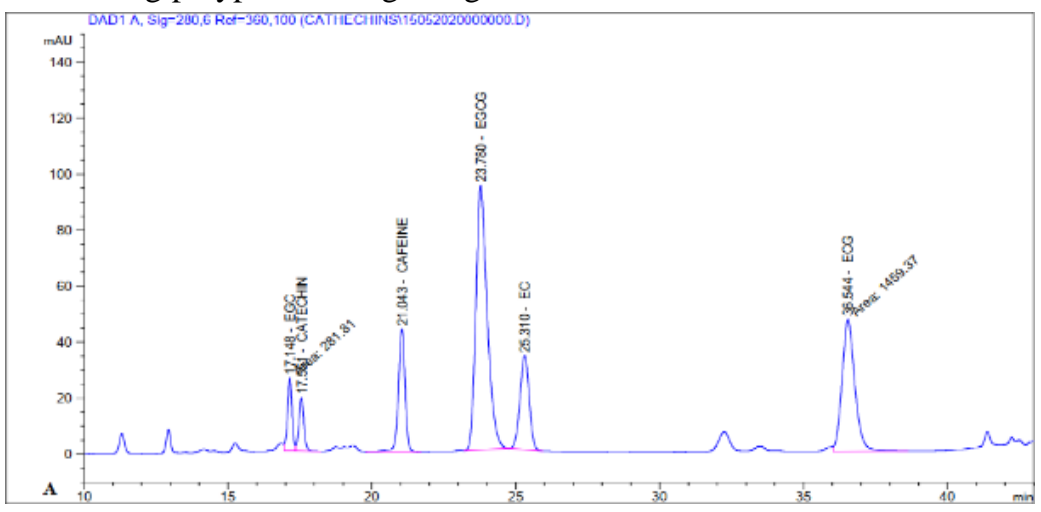

Hình 2. Hàm lượng các dẫn xuất catechin và caffeine trong mẫu cao chiết đo bằng phương pháp HPLC-UV

Kết quả phân tích HPLC-Uvis cho thấy, hàm lượng các dẫn xuất catechin trong mẫu cao chiết khá cao, tăng dần theo thứ tự catechin $<$ ECG $<$ EC $<$ EGCG $<$ EGC được thể hiện ở Hình 2, đạt hàm lượng 537,65 mg/g GAE. Hàm lượng $\mathrm{EGC}$ và $\mathrm{EGCG}$ đạt hàm lượng cao nhất lần lượt là 188,59 và $167,5 \mathrm{mg} / \mathrm{g}$ GAE chiếm $35,08 \%$ và $31,15 \%$ trong nhóm hợp chất. $\mathrm{EC}$ và $\mathrm{ECG}$ đạt khối lượng xấp xỉ nhau với giá trị là 85,53 và $67,77 \mathrm{mg} / \mathrm{g}$ GAE cao chiết chiếm $15,91 \%$ và $12,61 \%$. Catechin đạt hàm lượng thấp nhất 5,26\% $(28,26 \mathrm{mg} / \mathrm{g} \mathrm{GAE})$. Hàm lượng caffeine chiếm $3,78 \%$.

\subsection{Kết quả khảo sát tỷ lệ phối trộn cỏ ngọt tạo vị ngọt cho sản phẩm}

Kết quả khảo sát các sản phẩm trà hòa tan trên thị trường cho thấy một đơn vị sản phẩm được hòa tan trong khoảng $100 \mathrm{~mL}$ nước nóng, tức là vừa đủ cho một lần sử dụng. Vì vậy, trong nghiên cứu này lượng cỏ ngọt được chọn để khảo sát là 0,$025 ; 0,05$; 0,$075 ; 0,1$ và $0,125 \mathrm{~g}$ hòa tan trong $100 \mathrm{~mL}$ nước 85 $90^{\circ} \mathrm{C}$.
Bột cao chiết cỏ ngọt trong nghiên cứu này được sử dụng để tạo độ ngọt thanh cho sản phẩm trà hoà tan, tuy nhiển màu của cao chiết cỏ ngọt có ảnh hưởng nhất định đến màu sắc chung của sản phẩm, do đó trong thí nghiệm này chỉ tiến hành đánh giá cảm quan về độ ngọt của dịch cỏ ngọt để tìm ra nghiệm thức cho vị ngọt vừa phải để tiến hành phối trộn với cao chiết trà xanh ở thí nghiệm sau.

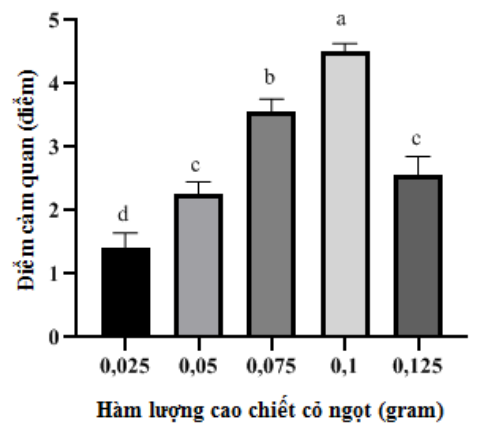

Hình 3. Kết quả đánh giá cảm quan hàm lượng cao chiết cỏ ngọt hòa tan vào nước

Ghi chú: $a, b, c, d(p<0,05)$ là các khác biệt có ý nghĩa thống kê ở độ tin cậy $95 \%$. 
Qua kết quả ở Hình 3 cho thấy hàm lượng cao chiết cỏ ngọt ở nghiệm thức $0,1 \mathrm{~g}$ được đánh giá cảm quan tốt nhất, ở nghiệm thức này sản phẩm có độ ngọt thanh, vừa phải, dễ chịu khi uống. Nghiệm thức $0,075 \mathrm{~g}$ cho kết quả đánh giá cảm quan cũng tương đối tốt, sản phẩm nghiệm thức này có vị ngọt nhẹ và thanh, tuy nhiên độ ngọt không đủ để kích thích vị giác của người dùng. Mặc khác, ở nghiệm thức 0,05 $\mathrm{g}$ và $0,125 \mathrm{~g}$ thì không được đánh giá cao, kết quả này không có sự khác biệt, theo đánh giá của đa số của đánh giá viên thì sản phẩm bổ sung cỏ ngọt ở nghiệm thức $0,05 \mathrm{~g}$ có vị nhạt, độ ngọt hầu như không cảm nhận được, còn đối với nghiệm thức bổ sung $0,125 \mathrm{~g}$ cỏ ngọt có vị ngọt gắt, tạo cảm giác khó chịu cho vùng lưỡi và vòm họng. Nghiệm thức $0,025 \mathrm{~g}$ có kết quả đánh giá cảm quan thấp nhất, theo nhận xét của các đánh giá viên thì hàm lượng cỏ ngọt quá ít nên không cảm nhận được độ ngọt. Tóm lại, từ kết quả phân tích trên cho thấy với lượng cao cỏ ngọt $0,1 \mathrm{~g}$ có điểm cảm quan trung bình cao nhất khi hòa tan trong $100 \mathrm{~mL}$ nước, dịch trà cho vị ngọt thanh, dễ chịu, đặc trưng của cỏ ngọt, phù hợp với thị hiếu người tiêu dùng.

\subsection{Kết quả khảo sát công thức phối trộn bột trà catechin}

Phép thử cho điểm thị hiếu dựa trên thang điểm 6 bậc của tiêu chuẩn Việt Nam TCVN 3215-79 được 20 đánh giá viên sử dụng để đánh giá cảm quan màu sắc và mùi vị của các nghiệm thức phối trộn. Kết quả cho điểm cảm quan được trình bày cụ thể ở biểu đồ Hình 4.

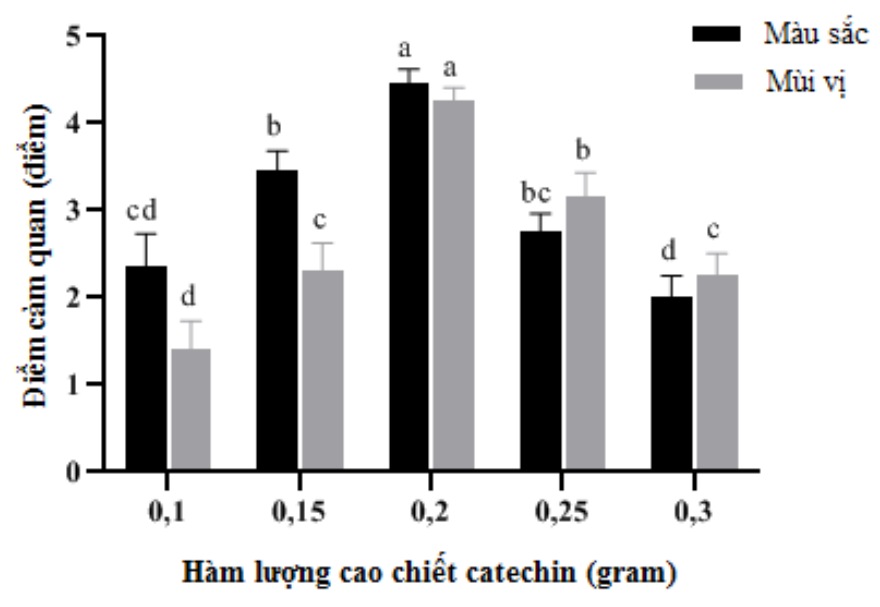

Hình 4. Kết quả đánh giá cảm cảm quan màu sắc và mùi vị của các nghiệm thức phối trộn bột cao chiết catechin và cỏ ngọt

Ghi chú: $a, b, c, d(p<0,05)$ là các khác biệt có ý nghĩa thống kê ở độ tin cậy 95\%
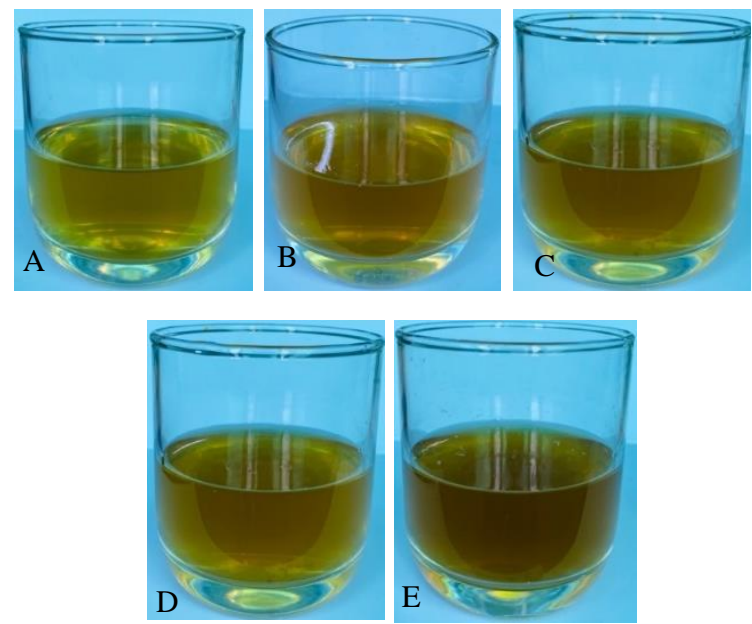

Hình 5. Màu sắc của các nghiệm thức phối trộn bột trà catechin

Ghi chú: $A, B, C, D, E$ là hàm lượng bổ sung cao chiết catechin lần luợt tù̀ 0,$1 ; 0,15 ; 0,2 ; 0,25$ và $0,3 \mathrm{~g}$ 
Về màu sắc, nhìn chung theo nhận xét của các đánh giá viên, phổ màu trà ở các nghiệm thức đều ở mức chấp nhận được. Nghiệm thức bổ sung $0,2 \mathrm{~g}$ cao chiết catechin có điểm cảm quan màu sắc trung bình cao nhất và được đa số các đánh giá viên nhận nước trà có độ trong, vàng nâu, đặc trưng cho loại trà tốt. Màu sắc sản phẩm nước trà ở nghiệm thức bổ sung $0,15 \mathrm{~g}$ cao chiết cũng được đánh giá khá cao, vẫn có độ trong, sáng, vàng nâu đặc trưng của trà. Tuy nhiên, ở nghiệm thức này màu trà nhạt hơn so với nghiệm thức bổ sung $0,2 \mathrm{~g}$ nên không được đánh giá cao bằng. Nghiệm thức bổ sung 0,1 và 0,25 $\mathrm{g}$ cao chiết catechin có điểm đánh giá cảm quan không cao và giữa kết quả đánh giá cảm quan ở hai nghiệm thức này không có sự khác biệt có nghĩa về mặt thống kê. Theo nhận xét của các đánh giá viên thì nghiệm thức bổ sung $0,1 \mathrm{~g}$ có màu trà tương đối nhạt, còn nghiệm thức bổ sung $0,25 \mathrm{~g}$ có màu đậm và tối, cho nên màu sắc sản phẩm ở hai nghiệm thức này không được ưa thích. Khi tăng lượng cao chiết lên $0,3 \mathrm{~g}$ thì nước trà trở nên đậm và tối màu, gây khó chịu cho người sử dụng, do đó điểm cảm quan thấp nhất là 2,00 điểm. Tóm lại, ở tỷ lệ phối trộn 0,1 $\mathrm{g}$ bột cao chiết cỏ ngọt và $0,2 \mathrm{~g}$ bột cao chiết trà xanh khi hòa tan vào $100 \mathrm{~mL}$ nước cho nước trà có độ trong, sáng, màu vàng nâu, đẹp, đặc trưng cho loại trà tốt, phù hợp với thị hiếu người tiêu dùng.

Về mùi vị sản phẩm, nghiệm thức bổ sung $0,2 \mathrm{~g}$ cao chiết catechin vẫn tiếp tục được đánh giá là tốt nhất. Ở nghiệm thức này, sản phẩm có độ trung hoà về vị thể hiện được vị ngọt thanh của cỏ ngọt và độ chát vừa phải, đặc trưng của trà. Kế đến là nghiệm thức bổ sung $0,25 \mathrm{~g}$ có điểm đánh giá cảm quan thấp hơn. Ở nghiệm thức này, sản phẩm có độ trung hoà về vị, thể hiện độ ngọt vừa phải, hương thơm đặc trưng của trà, tuy nhiên độ chát hơi nhiều nên có một số đánh giá viên không ưa thích. Nghiệm thức bổ sung 0,15 và $0,3 \mathrm{~g}$ cao chiết có điểm đánh giá gần như là tương đương nhau không có sự khác biệt về mặt thống kê. Ở nghiệm thức bổ sung $0,17 \mathrm{~g}$ catechin, sản phẩm có độ ngọt cao nên làm mất đi độ chát và mùi đặc trưng của trà. Ngược lại, nghiệm thức bổ sung $0,3 \mathrm{~g}$ có hàm lượng trà nhiều nên sản phẩm có độ chát quá cao, làm cho các đánh giá viên có cảm giác có vị gắt khi sử dụng. Nhìn chung ở 2 nghiệm thức này, sản phẩm không được đánh giá cao về màu sắc lẫn mùi vị của sản phẩm. Cuối cùng là nghiệm thức có hàm lượng cao chiết catechin thấp nhất $(0,1 \mathrm{~g})$ nên các đánh giá viên không cảm nhận được mùi vị của trà và được đánh giá cảm quan thấp nhất.

Tóm lại, ở tỷ lệ phối trộn $0,1 \mathrm{~g}$ cao chiết cỏ ngọt và $0,2 \mathrm{~g}$ cao chiết catechin (tỷ lệ $1: 2$ ) khi hòa tan với $100 \mathrm{~mL}$ nước đạt được điểm cảm quan trung bình cao nhất, thể hiện được độ trung hoà về vị, ngọt thanh và chát vừa với vị chát đặc trưng cho trà xanh, phù hợp với thị hiếu người tiêu dùng. Từ 2 kết quả trên cho thấy, nghiệm thức bổ sung $0,2 \mathrm{~g}$ cao chiết catechin đều có điểm cảm quan trung bình về màu sắc và vị cao nhất. Do đó, nghiệm thức này được chọn để sử dụng để phối trộn với maltodextrin và sấy phun để tạo sản phẩm hoàn thiện nhất.

\section{4. Ảnh hưởng của nồng độ chất khô đến hiệu suất thu hồi sản phẩm bằng công nghệ sấy phun}

Tỷ lệ phối trộn hỗn hợp cao chiết catechin : cỏ ngọt : maltodextrin trên một đơn vị sản phẩm có khối lượng $3 \mathrm{~g}$ là $0,2: 0,1: 2,7$ (w:w:w) và tương ứng với tỷ lệ $2: 1: 27$. Sự ảnh hưởng của nồng độ chất khô đến hiệu suất thu hồi sản phẩm bằng công nghệ sấy phun được khảo sát ở 4 nồng độ chất khô là 9,12 , 15 và $18 \%$ cho kết quả như ở Bảng 1 .

Bảng 1. Hiệu suất thu hồi sản phẩm sấy phun

\begin{tabular}{cccc}
\hline $\begin{array}{c}\text { Nghiệm } \\
\text { thức }\end{array}$ & $\begin{array}{c}\text { Khối lượng hốn hợp trước } \\
\text { sấy phun }(\mathbf{g})\end{array}$ & $\begin{array}{c}\text { Khối lượng hỗn hợp sau sấy } \\
\text { phun }(\mathbf{g})\end{array}$ & $\begin{array}{c}\text { Hiệu suất thu hồi sản } \\
\text { phẩm }(\%)\end{array}$ \\
\hline $9 \%$ & 9 & 5,98 & 66,44 \\
$12 \%$ & 12 & 8,85 & 73,75 \\
$15 \%$ & 15 & 12,48 & 83,20 \\
$18 \%$ & 18 & Không tan hoàn toàn & - \\
\hline
\end{tabular}

Kết quả cho thấy, hiệu suất thu hồi sản phẩm sấy phun tăng dần từ nồng độ $9 \%$ đến $15 \%$ và cao nhất ở nghiệm thức có nồng độ chất khô $15 \%$ là $83,20 \%$. So với nghiên cứu của Salvador et al. (2009) cũng cho kết quả gần như tương đồng về hiệu suất thu hồi sản phẩm sau sấy phun với giá trị là $84,10 \%$. Màu sắc và mùi vị trà ở các nghiệm thức không bị thay đổi sau sấy phun.

Maltodextrin vừa là chất hỗ trợ hòa tan, vừa là chất độn trong quá trình sấy phun làm tăng hiệu suất thu hồi của bột sau khi sấy.Tuy nhiên, khi tăng nồng độ chất khô lên $18 \%$, hỗn hợp phối trộn có dấu hiệu không tan hoàn toàn, nguyên nhân có thể do nồng 
độ chất khô bổ sung vào quá cao làm dung dịch đạt trạng thái bão hòa độ hòa tan nên hỗn hợp dung dịch không tan hoàn toàn. Vì vậy, nồng độ chất khô trong sấy phun ở nghiệm thức $15 \%$ là tốt nhất và được chọn để sản xuất sản phẩm trà hòa tan. Sản phẩm sấy phun trà hoà tan catechin có màu vàng trắng sáng, cấu trúc bột mịn như sữa bột, sản phẩm tan hoàn toàn trong nước, độ ẩm của sản phẩm sau sấy phun là $5,6-6,1 \%$ (Hình 6).

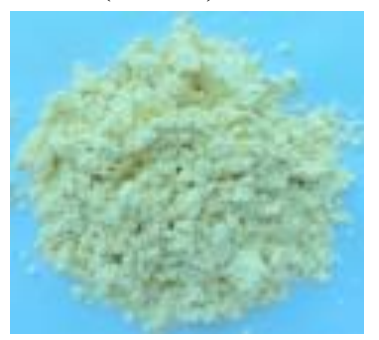

Hình 6. Bột thành phẩm trà hòa tan catechin sau sấy phun

\subsection{Bước đầu xây dựng tiêu chuẩn cơ sở trà hòa tan catechin}

Bột thành phẩm trà hòa tan catechin sau khi sấy phun sẽ được phân tích các chỉ tiêu vi sinh và hóa lý để đánh giá được chất lượng và độ an toàn của sản phẩm. Kết quả được trình bày cụ thể ở Bảng 2 .

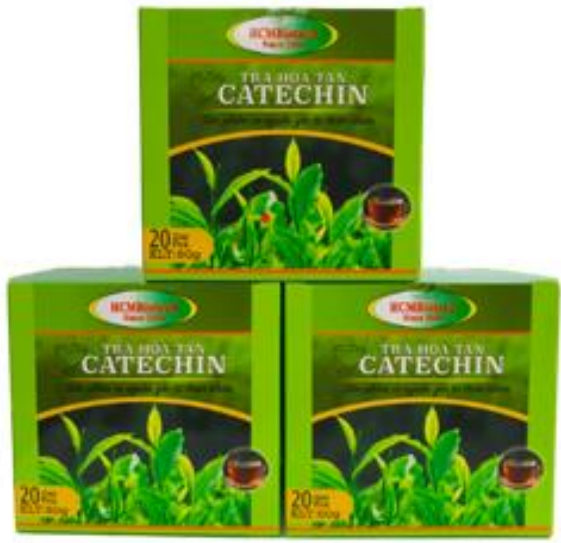

Hình 7. Sản phẩm trà hòa tan

Bảng 2. Các chỉ tiêu trong bộ tiêu chuẩn cơ sở sản phẩm trà hòa tan catechin

\begin{tabular}{|c|c|c|c|}
\hline Chỉ tiêu & Bộ tiêu chuẩn & $\begin{array}{l}\text { Giới hạn tiêu } \\
\text { chuẩn }\end{array}$ & $\begin{array}{l}\text { Kết quả phân } \\
\text { tích }\end{array}$ \\
\hline $\begin{array}{l}\text { Tổng số vi sinh vật hiếu khí (khuẩn } \\
\text { lạc/g sản phẩm) }\end{array}$ & $\begin{array}{l}\text { TCVN 4884:2005 } \\
\text { (ISO 4833:2003) }\end{array}$ & $<10^{3} \mathrm{cfu} / \mathrm{g}$ & $70 \mathrm{cfu} / \mathrm{g}$ \\
\hline Coliform (khuẩn lạc/g sản phẩm) & $\begin{array}{l}\text { TCVN 6848:2007 } \\
\text { (ISO 4832-2007) }\end{array}$ & $<10^{1} \mathrm{cfu} / \mathrm{g}$ & Không phát hiện \\
\hline Nấm men (khuẩn lạc/g sản phẩm) & $\begin{array}{l}\text { TCVN 8275-1:2010 } \\
\text { (ISO 21527-1:2008) }\end{array}$ & $<10^{2} \mathrm{cfu} / \mathrm{g}$ & Không phát hiện \\
\hline Nấm mốc (khuẩn lạc/g sản phẩm) & $\begin{array}{l}\text { TCVN 8275-1:2010 } \\
\text { (ISO 21527-1:2008) }\end{array}$ & $<10^{1} \mathrm{cfu} / \mathrm{g}$ & $10 \mathrm{cfu} / \mathrm{g}$ \\
\hline Salmonella (khuẩn lạc/25 g sản phẩm) & $\begin{array}{l}\text { TCVN 4829:2005 } \\
\text { (ISO 6579:2004) }\end{array}$ & $<10^{1} \mathrm{cfu} / \mathrm{g}$ & Không phát hiện \\
\hline $\begin{array}{l}\text { Hàm lượng aflatoxin tổng } \\
(\mathrm{B} 1+\mathrm{B} 2+\mathrm{G} 1+\mathrm{G} 2),(\mu \mathrm{g} / \mathrm{kg})\end{array}$ & $\begin{array}{l}\text { TCVN 7596:2007 } \\
\text { (ISO 16050:2003) }\end{array}$ & Không phát hiện & Không phát hiện \\
\hline $\begin{array}{l}\text { Hàm lượng chất tan trên chất khô tính } \\
\text { theo khối lượng }(\%)\end{array}$ & $\begin{array}{l}\text { TCVN 5610:2007 } \\
\text { (ISO 9768-1994) }\end{array}$ & $>32 \%$ & $100 \%$ \\
\hline $\begin{array}{l}\text { Hàm lượng tro tổng trên chất khô tính } \\
\text { theo khối lượng }(\%)\end{array}$ & $\begin{array}{l}\text { TCVN 5611:2007 } \\
\text { (ISO 1575-1987) }\end{array}$ & $4-8 \%$ & $7,45 \%$ \\
\hline $\begin{array}{l}\text { Hàm lượng tro tan trong nước trên chất } \\
\text { khô tính theo khối lượng }(\%)\end{array}$ & $\begin{array}{l}\text { TCVN 5084:1990 } \\
\text { (ISO 1576-1975) }\end{array}$ & $>45 \%$ & $97,45 \%$ \\
\hline $\begin{array}{l}\text { Độ kiềm của tro tan trong nước trên chất } \\
\text { khô tính theo khối lượng }(\%)\end{array}$ & $\begin{array}{l}\text { TCVN 5085:1990 } \\
\text { (ISO 1578-1975) }\end{array}$ & $1-3 \%$ & $1,15 \%$ \\
\hline $\begin{array}{l}\text { Hàm lượng tro không tan trong } \mathrm{HCl} \text { trên } \\
\text { chất khô tính theo khối lượng }(\%)\end{array}$ & $\begin{array}{l}\text { TCVN 5612:2007 } \\
\text { (ISO 1577-1987) }\end{array}$ & Không phát hiện & Không phát hiện \\
\hline $\begin{array}{l}\text { Hàm lượing xơ thô trên chất khô tính } \\
\text { theo khối lượng }(\%)\end{array}$ & $\begin{array}{l}\text { TCVN 5103:1990 } \\
\text { (ISO 5498-1981) }\end{array}$ & Không phát hiện & Không phát hiện \\
\hline Hàm lượng các dẫn xuất catechin (mg/g) & $\begin{array}{l}\text { TCVN 9745-1:2013 } \\
\text { (ISO 14502-1:2005) }\end{array}$ & - & 11,13 \\
\hline
\end{tabular}


Bột trà hòa tan thành phẩm sau đó được phân tích đánh giá các chỉ tiêu hóa học cũng như các chỉ tiêu vi sinh. Kết quả phân tích cho thấy các chỉ tiêu phân tích phù hợp với tiêu chuẩn Việt Nam (TCVN) đồng thời cũng phát hiện có sự hiện diện của hợp chất catechin là $11,13 \mathrm{mg} / \mathrm{g}$.

Bột trà hòa tan thành phẩm được kiểm tra về các chỉ tiêu cảm quan, phân tích sơ bộ thành phần hóa học. Kết quả phân tích cho thấy hàm lượng chất tan tốt đạt $100 \%$ so với giới hạn phát hiện TCVN 6510 (ISO 9768) là không nhỏ hơn $32 \%$. Hàm lượng tro tổng số đạt 7,45\% phù hợp với TCVN 5611 (ISO 1575 ) nằm trong khoảng $4-8 \%$. Hàm lượng tro tan trong nước chỉ đạt $97,45 \%$ cao hơn nhiều so với TCVN 5084 (ISO 1576) yêu cầu không nhỏ hơn $45 \%$. Độ kiềm của tro tan trong nước là $1,15 \%$ cho kết quả tốt so với TCVN 5085 (ISO 1578) là 1-3\%.

Ngoài ra, kết quả phân tích vi sinh đều nằm trong khoảng giới hạn cho phép được quy định tại các bộ tiêu chuẩn TCVN. Cụ thể, tổng số vi sinh vật hiếu khí là $70 \mathrm{cfu} / \mathrm{g}$ thấp hơn so với yêu cầu là nhỏ hơn $10^{3} \mathrm{cfu} / \mathrm{g}$. Các chỉ tiêu Coliform, nấm men, Salmonella, hàm lượng aflatoxin tổng đều cho kêt quả là không phát hiện có trong mẫu sản phẩm. Với chỉ tiêu nấm mốc thì phát hiện có $10 \mathrm{cfu} / \mathrm{g}$ sản phẩm nhưng vẫn nằm trong khoảng giới hạn cho phép là nhỏ hơn $10^{2} \mathrm{cfu} / \mathrm{g}$.

Bên cạnh đó, kết quả phân tích không phát hiện hàm lượng tro không tan trong $\mathrm{HCl}$, hàm lượng xơ thô và hàm lượng aflatoxin tổng, phù hợp với các quy định TCVN. Nhìn chung, Sản phâm trà hòa tan catechin đạt tiêu chuất chất lượng, các chỉ tiêu phân tích sản phẩm đều nằm trong khoảng giới hạn cho phép dựa trên các TCVN hiện hành.

\section{KẾT LUẬN}

Nghiên cứu đã xác định được hiệu suất thu hồi cao chiết catechin tương đối cao với giá trị đạt $30,91 \%$ ở điều kiện chiết nóng $80^{\circ} \mathrm{C}$ trong 1 giờ. Hàm lượng polyphenol tổng trong mẫu cao chiết là $327,47 \mathrm{mg} \mathrm{GAE} / \mathrm{g}$ cao chiết và hàm lượng tổng các dẫn xuất catechin là $537,65 \mathrm{mg} / \mathrm{g}$ GAE. Đã xây dựng được thành phần công thức phối trộn trà hòa tan catechin giữa cao chiết catechin, cỏ ngọt và nước với hàm lượng tương ứng là $0,2 \mathrm{~g}, 0,1 \mathrm{~g}$ trong $100 \mathrm{~mL}$ nước. Khảo sát được ở nồng độ chất khô $15 \%$ sẽ cho hiệu suất thu hồi sản phẩm tốt nhất bằng công nghệ sấy phun với giá trị là $83,20 \%$, chất lượng sản phẩm sau sấy phun không bị thay đổi về mùi vị và màu sắc. Kết quả đánh giá phân tích các chỉ tiêu vi sinh, hóa lý và hàm lượng các chất đều nằm trong khoảng giới hạn an toàn và phù hợp với bộ tiêu chuẩn đánh giá TCVN của nước ta.

\section{LỜI CẢM ƠN}

Kinh phí thực hiện nghiên cứu này được cung cấp bởi Trung tâm Công nghệ Sinh học TP. Hồ Chí Minh.

\section{TÀI LIỆU THAM KHẢO}

Blanco, A.R., Sudano, R.A., Spoto, G.C., Nostro, A. \& Rusciano, D. (2005). Epigallocatechin gallate inhibits biofilm formation by ocular staphylococcal isolates. Antimicrob Agents Chemother, 49(10), 4339-4343.

Bộ Khoa học và Công nghệ. (1990a). Chè xác định độ kiềm của tro tan trong nước (TCVN 5085:1990 (ISO 1578-1975)). https://vanbanphapluat.co/tcvn-5085-1990-chexac-dinh-do-kiem-cua-tro-tan-trong-nuoc

Bộ Khoa học và Công nghệ. (1990b). Xác định tro tan trong nước và tro không tan trong nước (TCVN 5084:1990 (ISO 1576-1975)).

https://vanbanphapluat.co/tcvn-5084-1990-che-xacdinh-tro-tan-trong-nuoc-tro-khong-tan-trong-nuoc

Bộ Khoa học và Công nghệ. (2005a). Vi sinh trong thực phẩm và thức ăn chăn nuôi, phuoong pháp định luợng vi sinh vạt trên đĩa thach (TCVN 4884:2005 (ISO 4833:2003)). https://vanbanphapluat.co/tcvn-4884-2005-kythuat-dem-khuan-lac-o-30-do-c\#toan-van

Bộ Khoa học và Công nghệ. (2005b). Vi sinh trong thực phẩm và thức ăn chăn nuôi, phuoong pháp phát hiện Salmonella trên đĩa thạch (TCVN 4829:2005 (ISO 6579:2004)). https://vanbanphapluat.co/tcvn-4829-2005-visinh-vat-trong-thuc-pham-va-thuc-an-chan-nuoi

Bộ Khoa học và Công nghệ. (2007a). Vi sinh trong thực phẩm và thức ăn chăn nuôi, phương pháp dịnh luơng coliform (TCVN 6848:2007 (ISO 4832-2007)). https://vanbanphapluat.co/tcvn6848-2007vi-sinh-vat-trong-thuc-pham-va-thucan-chan-nuoi

Bộ Khoa học và Công nghệ. (2007b). Xác định hàm luợng chất chiết trong nước (TCVN 5610:2007 (ISO 9768-1994)). https://vanbanphapluat.co/tcvn5610-2007-che-xac-dinh-ham-luong-chat-chiettrong-nuoc\#toan-van

Bộ Khoa học và Công nghệ. (2007c). Xác định không tan trong acid (TCVN 5612:2007 (ISO 15771987)). https://vanbanphapluat.co/tcvn-5612-2007che-xac-dinh-tro-khong-tan-trong-axit

Bộ Khoa học và Công nghệ. (2007d). Xác định tro tổng số (TCVN 5611:2007 (ISO 1575-1987)). https://vanbanphapluat.co/tcvn-5611-2007-chexac-dinh-tro-tong-so 
Bộ Khoa học và Công nghệ. (2010). Vi sinh trong thực phẩm và thức ăn chăn nuôi, phuoong pháp định lự̛ng nấm men nấm mốc (TCVN 82751:2010 (ISO 21527-1:2008)).

https://vanbanphapluat.co/tcvn-8275-1-2010-visinh-vat-trong-thuc-pham-thuc-an-chan-nuoi

Bộ Khoa học và Công nghệ. (2013). Xác định các chất đặc trung của chè xanh và chè đen (TCVN 9745-1:2013 (ISO 14502-1:2005)).

https://vanbanphapluat.co/tcvn-9745-1-2013xac-dinh-chat-dac-trung-che-xanh-che-den-hamluong-polyphenol

Cabrera, C., Artacho, R. \& Giménez, R. (2006). Beneficial effects of green tea-a review. Journal of the American College of Nutrition, 25(2), 79-99.

Cục kiểm tra chất lượng sản phẩm và hàng hóa. (2018). Sản phẩm thực phẩm phân tích cảm quan phuoong pháp cho điểm (TCVN 3219 - 79). https://luattrongtay.vn/ViewFullText/Id/de871d1 e-d03e-4a99-8295-8ce320febd3a

Đặng Thị Yến \&, Đặng Quốc Tiến. (2018). Nghiên cứu quy trình sản xuất trà bụt giấm hòa tan. Tạp chi khoa học và công nghệ thực phẩm, 15(1), 95-105.

Ly, B. T. K. \& Chi, H. T. (2015). Role of EGCG in regulation tyrosine kinase onco-proteins in cancer. In Powell, N. (Ed.) Green tea and health antioxidant properties, consumption and role in disease prevention. Nova Science Publishers.

Marja, P. K., Anu, I. H., Heikki, J. V., Jussi, P. P. R., Kalevi, P. \& Tytti, S. K. (1999). Antioxidant activity of plant extracts containing phenolic compounds. Journal of Agricultural and Food Chemistry, 47(10), 3954 - 3962.

Mueller, M., Hobiger, S. \& Jungbauer A. (2010). Anti-inflammatory activity of extracts from fruits, herbs and spices. Food chemistry, 122(4), 987-996.

Nguyễn Xuân Duy, Hồ Bá Vương (2013). Hoạt tính chống oxi hóa và ức chế enzyme polyphenoloxidase của một số loại thực vật ăn được ở Việt Nam. Tạp chí Khoa học và Phát triển, 11(3), 364-372.

Perva, U. A., Škerget, M., Knez, Ž., Weinreich, B., Otto, F. \& Grüner, S. (2006). Extraction of active ingredients from green tea (Camellia sinensis): Extraction efficiency of major catechins and caffeine. Food chemistry, 96(4), 597-605.

Salvador, G. P., Mirna, E. E., Juan, F. G. \& Isaac, A. G. (2009). Effect of the temperature on the spray drying of Roselle extracts (Hibiscus sabdariffa L.)". Plant Foods for Human Nutrition, 64(5), 62-67.

Tôn Nữ Liên Hương (2015). Chiết xuất stevioside từ cây cỏ ngọt (Stevia rebaudiana Bertoni). Tạp chi Khoa học Truòng Đại học Cần Tho, 36(2015), 73-76.

Tổng cục Tiêu chuẩn đo lường chất lượng. (2007). Xác định aflatoxin $B 1$ và hàm lương tồng aflatoxin B1, B2, G1 và G2 trong ngủ cốc, các loại hạt và các sản phẩm của chúng, phuơng pháp sắc ký lỏng hiệu năng cao (TCVN 7596:2007 (ISO 16050:2003)). https://vanbanphapluat.co/tcvn7596-2007-thuc-pham-xac-dinh-aflatoxin-b1-hamluong-tong-so-aflatoxin

Ủy ban Khoa học nhà nước. (1990). Xác định hàm luợng xo thô (TCVN 5103:1990 (ISO 54981981)). https://vanbanphapluat.co/tcvn-51031990-nong-san-thuc-pham-xac-dinh-ham-luongxo-tho

Vuong, V. Q., Sathira, H., Paul, D. R., Michael, C. B., Phillips, P. A. \& Christopher J. S. (2013). Effect of extraction conditions on total phenolic compounds and antioxidant activities of Carica papaya leaf aqueous extracts. Journal of Herbal Medicine, 3(3), 104-111.

Wang, H., Provan, G. J. \& Helliwell, K. (2003). HPLC determination of catechins in tea leaves and tea extracts using relative response factors. Food Chemistry, 81(2), 307-312. 